\title{
Combustion and emission characteristics of a compression ignition engine operated on dual fuel mode using renewable and sustainable fuel combinations
}

\author{
V. S. Yaliwal ${ }^{1} \cdot$ N. R. Banapurmath ${ }^{2}$
}

Received: 21 August 2020 / Accepted: 19 December 2020 / Published online: 7 January 2021

(c) The Author(s) 2020 OPEN

\begin{abstract}
The present experimental study aims to examine the combustion and emission characteristics of a single cylinder four stroke direct injection diesel engine operated in dual fuel mode using dairy scum oil methyl ester (DiSOME) and its blend (B20) - producer gas combination with and without addition of hydrogen. DiSOME/B20-producer gas combination without hydrogen addition exhibited inferior performance with increased hydrocarbon and carbon monoxide emissions owing to poor physic-chemical properties of both biodiesel and inducted low calorific value gas (producer gas) compared to the same fuel combination with hydrogen. Producer gas was inducted along with air, and hydrogen was allowed to mix with air-producer gas combination in the intake manifold. Experimental investigations were conducted at all load conditions and at constant flow rate of hydrogen $(8 \mathrm{lpm})$. It was noticed that that B20-hydrogen enriched producer gas combination with optimum parameters resulted in amplified thermal efficiency with reduced emission levels compared to the operation with B20/DiSOME-producer gas combination. However, investigation showed that diesel-producer gas combination with hydrogen addition provided amplified brake thermal efficiency by $3.8 \%, 16.4 \%$ and $13.2 \%$ compared to the diesel/DiSOME/B20 - producer gas combinations, respectively, at 80\% load. Hydrogen addition provided enhanced cylinder pressure and heat release rate with reduced emission levels except nitric oxide emissions. It can be concluded that the deprived combustion associated with DiSOME/B20-producer gas combination can be improved with hydrogen addition. The combination of DiSOME-producer gas operation with hydrogen addition is uniqueness of this present work.
\end{abstract}

Keywords Dairy scum oil methyl ester · Blended fuel · Producer gas · Hydrogen induction · Dual-fuel combustion · Emissions

\section{Introduction}

Diesel engines are more accepted for power generation applications due to its greater thermal efficiency with reduced $\mathrm{HC}$ and $\mathrm{CO}$ emissions caused by the greater compression ratio, lower fuel consumption and lower pumping losses. In addition, diesel engines can also operate on wide variety of fuels. In order to comprehensively utilize renewable fuels such as gaseous fuels in diesel engines, a dual fuel concept was developed. Investigations on the current archives of research, discovery of engine technologies enabled biodiesel utilization in diesel engines made very simpler and are now in the front position of engine technology discovery. Combustion of conventional fuels in internal combustion (IC) engines have brought decreased fossil fuel reserve in the earth crust and increased green house gas (GHG), this in turn contribute to global warming. Use of renewable fuels for internal combustion engine (IC) applications provide several solutions for the issues such as energy crises, depleting reserves and environmental

$\triangle$ V. S. Yaliwal, vsyaliwal2000@rediffmail.com | 'Department of Mechanical Engineering, SDM College of Engineering and Technology, Dharwad, Karnataka, India. ${ }^{2}$ BVB College of Engineering and Technology, KLE Technological University, Hubli, Karnataka, India. 
degradation and socio-economic issues as well [1]. In this context, investigators have reported that use of biodiesel and gaseous fuel operating on dual fuel mode is one of the promising solutions for saving pilot fuel consumption, reducing smoke and NOx emissions with acceptable levels of thermal efficiency. In addition, this can balance increased energy demand [2].

In India, waste production from municipal solid waste (MSW) and milk dairy has huge potential. Hence its utilization for shaft power applications can save a crude oil and large amount of investment in foreign exchange. It is noticed that, India is producing about 55 million tons of municipal solid waste (MSW) per year and can increase nearly about $5 \%$ by every year $[3,4]$. Similarly, biodegradable waste such as dairy scum produced in India and is more than 150 Million tonnes per year and large scale milk dairy can processes nearly about 5,00,000 L of milk per day. Such a milk dairy can alone generate $200-350 \mathrm{~kg}$ of effluent scum per day approximately. Most of the dairies dispose this scum in a waste disposal site. Therefore, an effective strategy for managing and controlling the waste is necessary because to prevent the environmental degradation. Hence treatment of different waste in different ways needs to be addressed, thereby reducing the waste that may otherwise go to landfills.

In this context, it is observed that very small number of literatures are proposed on the utilization of dairy scum oil biodiesel and producer gas for diesel engine applications. Several researchers have given contradictory statements i.e., use of biodiesel produces same, low or more power output compared to diesel with decreased and/ or increased net carbon dioxide, hydrocarbon, carbon monoxide, and particulate matter emissions. However, maximum fuel consumption has been reported due to inferior properties of biodiesel compared to diesel fuel [5-8]. Increased ignition delay and combustion duration, decreased cylinder pressure and heat release rate while increased brake specific fuel consumption and exhaust gas temperature has been reported [1]. Investigators recommended only non-edible oils for engine applications. In view of this, dairy scum oil biodiesel production using modified eggshell derived nano calcium oxide has been reported. They found $96 \%$ conversion at 6:1 molar ratio of methanol, 2.4 wt $\%$ catalyst amount, $65{ }^{\circ} \mathrm{C}$ reaction temperature and $3 \mathrm{~h}$ reaction time. They observed comparable results compared to diesel operation in terms of thermal efficiency and specific fuel consumption. Lower NOx levels have been reported compared to diesel operation [9-11]. Combustion and emission characteristics of a diesel engine using graphene oxide nano-particles added dairy scum oil methyl ester-diesel blends has been stated [12]. Surfactant such as sodium dodecyl sulfate (SDS) was used to achieve steady dispersion of graphene oxide in the dairy scum oil methyl ester-diesel blends. They showed that at optimum engine operating conditions and use $40 \%$ DiSOME and 20 ppm nano-particles in diesel fuel provided increased thermal efficiency by $11.56 \%$ with reduced specific fuel consumption and emission levels. Combustion and tail pipe emissions from a dual fuel engine operated on DiSOME and compressed natural gas (CNG) combinations have been examined [13]. They found amplified combustion rate with lower emissions at optimized parameters of injection pressure (230 bar), injection timing $\left(29^{\circ}\right.$ bTDC), and compression ratio (18) and Bio-CNG flow rate $(0.48 \mathrm{~kg} / \mathrm{h})$.

Diesel engine operation functioning on single fuel mode using dairy scum biodiesel provided increased fuel consumption with increased smoke, $\mathrm{HC}$ and $\mathrm{CO}$ emissions. Hence, to recover the performance with diminished harmful exhaust from diesel engine operating on single fuel mode is modified to operate on dual fuel mode. In this direction, many researchers have investigated combustion and emission characteristics of diesel engine operated on dual fuel mode. Literature review on the gasification and its utilization for power generation applications has been reported. Dual-fuel engine performance significantly depends on the biomass physic-chemical properties, inducted and injected fuel type and moisture content, combustion stage, quantity of air utilization, air and fuel supply conditions and other variables. Dual fuel engine with producer gas always provide lower performance with amplified $\mathrm{HC}$ and $\mathrm{CO}$ emissions. However, $66 \%$ pilot fuel saving with drastic reduction in smoke and NOx emissions has been documented [1, 2]. Influence of pilot fuel quantity $(0.22,0.29$ and $0.35 \mathrm{~kg} / \mathrm{h})$ on the combustion and exhaust of a producer gas fuelled dual fuel engine has been examined. Amplified thermal efficiency, with declined pilot fuel saving and $\mathrm{CO}$ levels have been stated with an increased pilot fuel quantity [14]. Influence of various combustion chamber geometries on the combustion of Calophyllum Inophyllum methyl ester and babul wood chip derived producer gas combination has been reported [15]. Amplified exhaust gas temperature (EGT), thermal efficiency by $20.75 \%$ and reduced brake specific fuel consumption by $4.49 \%$ has been stated with toroidal re-entrant combustion chamber ( $\operatorname{TrCC}$ ) compared to hemispherical combustion chamber (HCC). Further, increased NOx levels by $19.9 \%$ and carbon dioxide emissions by $27.2 \%$ have been stated compared to the operation with HCC. Combustion and emission characteristics of a dual fuel engine operated on dual fuel mode using Honge oil methyl ester (HOME)-producer gas combination has been investaigated. They have optimized nozzle and combustion chamber geometry and similar trend of results have been reported. They showed $66.1 \%$ fuel saving with diesel and $63.2 \%$ with biodiesel based dual fuel operation [16]. 
However, several investigators have shwed pilot fuel savings about $90 \%$ with diesel based operation [15]. Further, dual fuel operation was carried out using diesel and sugarcane bagasse and carpentry waste derived producer gas combination. They found reduced thermal efficiency and NOx by $24.56 \%$ and $69.5 \%$ respectively at maximum load. They observed reduced fuel consumption by $45.71 \%$ with marginally amplified noise levels by $\sim 3.4 \mathrm{~dB}[17]$.

Investigators have proposed several techniques to enhance the performance of dual fuel engine namely injection timing advancing, increasing pilot fuel injection pressure and compression ratio and addition of hydrogen [18-20]. In view of this, effect of hydrogen addition on the combustion and emission characteristics of producer gas fuelled dual fuel engine has been investigated [20]. They have carried out experiments at a constant injection-pressure and pilot quantity for various injection timings and air-fuel ratios. They optimized injection timing at various air-fuel ratios to increase power output. They observed amplified thermal efficiency with increased hydrogen content in a producer gas. However, low power output has been stated with neat hydrogen-operation due to lean mixture. But improved performance with reduced smoke and marginally increased NOx has been reported [20]. Further, combustion duration and ignition delay variations with diesel and different hydrogen and producer gas combinations have been reported. They observed lower ignition delay and combustion duration compared to producer gas fuelled operation. They suggested that using producer gas and hydrogen in the proportion of 60:40 resulted in improved performance with comparable ignition delay and combustion duration [21]. Common rail direct injection diesel engine operated on dual fuel mode using neem biodiesel as injected pilot fuel and hydrogenproducer gas combination as inducted fuel. They kept constant flow rate of hydrogen ( $8 \mathrm{lpm})$, and used re-entrant combustion chamber, $10^{\circ}$ aTDC injection timing and at 900 bar injection pressure. They claimed 3.02\% increased brake thermal efficiency with $22.4 \%$ reduced smoke, $12.2 \%$ reduced $\mathrm{HC}, 10.8 \%$ reduced $\mathrm{CO}$, and $18.6 \%$ increased NOx levels compared to the same fuel combination with hemispherical combustion chamber [22].

From the literature review, it is noticed that few studies have been carried out on the extraction of fuels from waste and experimental investigations using diesel/biodiesel-enriched producer gas combinations. DiSOME/ blended fuel and producer gas operation with and without hydrogen operating on dual fuel mode is not investigated. In this context, both dairy scum oil methyl ester and producer gas were derived from waste (dairy scum and municipal solid waste) and are considered as renewable fuels to replace conventional fuel. In this present work, initially biomass was collected from municipal solid waste (MSW) and treated with waste frying oil (WFO) to achieve biodiesel treated biomass. Then waste frying oil treated biomass is dried completely and is used as a fuel for down draft gasfier. Gaseous fuel generated from down draft gasfier is called as producer gas or low calorific value gas. Similarly, DiSOME is produced using conventional transesterification process and is used as an injected pilot fuel. In the next phase of the work, and during the experimentation, generated producer gas was inducted along with air and mixed with hydrogen (8 Ipm) i.e., producer gas -hydrogen mixture was inducted along with air during suction stroke and is compressed. Further, DiSOME was injected into the engine cylinder at the end of compression stroke. So that liquid injected pilot fuel initiate the combustion. Further, feasibility of DiSOME and producer gas combination with and without hydrogen for power generation applications has been evaluated. Tests were conducted to investigate the performance, combustion and emission characteristics of a single-cylinder, four stroke, direct injection diesel engine operated on dual-fuel mode using DiSOME/B20-producer gas combination with and without hydrogen addition. Results of investigation are further compared with base line operation.

\section{Materials and methods}

In this present work, biodiesel and method of biomass preparation is discussed.

\subsection{Preparation of the biodiesel absorbed biomass}

Nearly about more than $450 \mathrm{~kg}$ of combustible biomass was extracted from the MSW in one week. Combustible biomass consists of different types of wood, straws, leaves and tree branches etc. called as mixed biomass. Further, combustible biomass were separated and cut into smaller size (one inch) approximately. For the gasification to generate a producer gas, biomass derived from MSW was changed to biodiesel absorbed biomass and is prepared as per the procedure and methods given in the literature [23]. For the present work, four vessels each having a capacity of $10 \mathrm{~kg}$ biomass was used and transferred all biomass into vessels. Then waste frying oil (WFO) obtained from restaurants was poured on the biomass contained in the vessels. Finally biomass was allowed to absorb WFO for 2 days. Then, biomass was put down on the ground and allowed to dry for 3-4 days at atmospheric temperature (mid day temperature was $38-41^{\circ} \mathrm{C}$ ), this in turn resulted into dried biomass. WFO absorbed biomass heating value was increased due to waste frying oil absorption. In addition, this may also, reduce the daily consumption of biomass used for dual fuel operation and increased gasifier 
loading time and combustion characteristics [23]. The properties of biomass before and after biodiesel absorption are presented in Tables 1, 2. Figure 1a-d illustrates the WFO absorption and WFO absorbed biomass.

\subsection{Properties of fuels used}

For dual fuel engine, biodiesel was obtained from dairy scum and was purchased from Karnataka Milk Federation, Dharwad. Its biodiesel was prepared at our college laboratory as per the procedure and methods [11]. Present work involves utilization of waste for diesel engine applications. Biodiesel obtained from dairy scum waste called as dairy scum oil methyl ester (DiSOME) and is used as injected pilot fuel or secondary fuel in a dual fuel engine. However, another waste is waste frying oil collected from the restaurants and is used to produce only biodiesel treated biomass (biodiesel absorbed biomass). Further, waste biomass obtained from MSW was changed to biodiesel absorbed biomass and is prepared as per the procedure and methods given in the literature [23]. Generated producer gas is used as primary fuel in a dual fuel engine. Hydrogen was purchased from local industry, Dharwad. In addition, proximate analysis of biomass with and without biodiesel absorption was carried out. Properties of fuels used are mentioned in Tables 1, 2, 3. The composition of producer gas derived from mixed biomass is shown in Table 3.

\section{Experimental setup and procedure}

Gasifier-engine system was developed and was made to operate on a dual fuel mode at fixed speed of $1500 \mathrm{rpm}$ and various engine loads. For the experimental investigation, a single cylinder four stroke water cooled direct injection diesel engine is used. The gasifier-engine arrangement with their specification is presented in Fig. 2 and Table 4.
Table 2 Properties of diesel, DiSOME and blended fuel

\begin{tabular}{llll}
\hline Property & Diesel & DiSOME & B20 \\
\hline Calorific value $(\mathrm{kJ} / \mathrm{kg})$ & 43,500 & 39,468 & 41,590 \\
$\begin{array}{l}\text { Density }\left(\mathrm{kg} / \mathrm{m}^{3}\right) \\
\text { Kinematic viscosity @ } 40^{\circ} \mathrm{C}\end{array}$ & 840 & 872 & 858 \\
$\quad\left(\mathrm{~mm}^{2} / \mathrm{s}\right)$ & & 4.8 & 4.1 \\
Flash point $\left({ }^{\circ} \mathrm{C}\right)$ & 56 & 215 & 118 \\
Fire point $\left({ }^{\circ} \mathrm{C}\right)$ & 68 & 226 & 132 \\
Cetane number & 54 & 60 & - \\
Carbon residue $(\%)$ & 0.21 & 0.46 & 0.31 \\
\hline
\end{tabular}

The diesel engine was suitably coupled to an eddy current dynamometer (Model: AG-10, $7.5 \mathrm{~kW}$ at 1500-3000 rpm) for loading. Low calorific value gas called as producer gas leaving at the underside of the gasifier is suitably cleaned and cooled using filter and counter flow heat exchanger respectively. The gas generated is subsequently mixed with air using carburettor or mixing chamber before it is entered into the cylinder during suction stroke. The capacity of downdraft gasifier used for the engine of $5.2 \mathrm{~kW}$ can handle $40 \mathrm{~kg} / \mathrm{h}$ of biomass. The engine had mechanical fuel injection system having 3 hole injector, each hole of $0.25 \mathrm{~mm}$ diameter. Experimentation was conducted with different test fuels and operating parameters shown in Table 5. Dried biodiesel treated biomass was loaded in the downdraft gasifier to obtain combustible gas. Producer gas flow rate was measured using a calibrated venturimeter and digital gas flow meter. Engine is provided with passages for cooling and is accomplished by circulating water through the engine block and cylinder head water passages. A piezoelectric transducer (Make: PCB Piezotronics, Model: HSM 111A22, Resolution: $0.145 \mathrm{mV} / \mathrm{kPa}$ ) was used to measure in-cylinder pressure and during investigation continuously 100 successive cycles at every load were documented in steps of 20 cycles. At a specified time, averaged pressure values were employed for combustion

Table 1 Properties of biomass and composition of producer gas

\begin{tabular}{|c|c|c|c|c|}
\hline Property & $\begin{array}{l}\text { Mixed biomass before bio- } \\
\text { diesel absorption }\end{array}$ & $\begin{array}{l}\text { Mixed biomass after bio- } \\
\text { diesel absorption }\end{array}$ & Property & $\begin{array}{l}\text { Composition } \\
\text { of producer } \\
\text { gas }\end{array}$ \\
\hline Moisture content (\% w/w) & 11.02 & 10.11 & $\mathrm{CO}, \%$ & $16-20$ \\
\hline Ash content $(w / w)$ & 0.91 & 0.98 & $\mathrm{H}_{2}, \%$ & $15-18$ \\
\hline Volatile matter (\%w/w) & 76 & 82.1 & Methane, \% & $1-6$ \\
\hline Fixed carbon (\%w/w) & 11.79 & 12.8 & $\mathrm{HC}, \%$ & $0.2-0.6$ \\
\hline Sulphur (\%w/w) & 0.09 & - & $\mathrm{N}_{2}, \%$ & $4.6-5.1$ \\
\hline Nitrogen $(\% \mathrm{w} / \mathrm{w})$ & 0.18 & 0.18 & Water vapor, \% & 4.21 \\
\hline Calorific value (kJ/kg) & $14,338.5$ & $18,880.6$ & $\mathrm{CO}_{2}, \%$ & $8-10$ \\
\hline Density $\left(\mathrm{kg} / \mathrm{m}^{3}\right)$ & 288 & 335 & Calorific value. $\mathrm{kJ} / \mathrm{kg}$ & 4236 \\
\hline
\end{tabular}


Fig. 1 Biodiesel absorption process
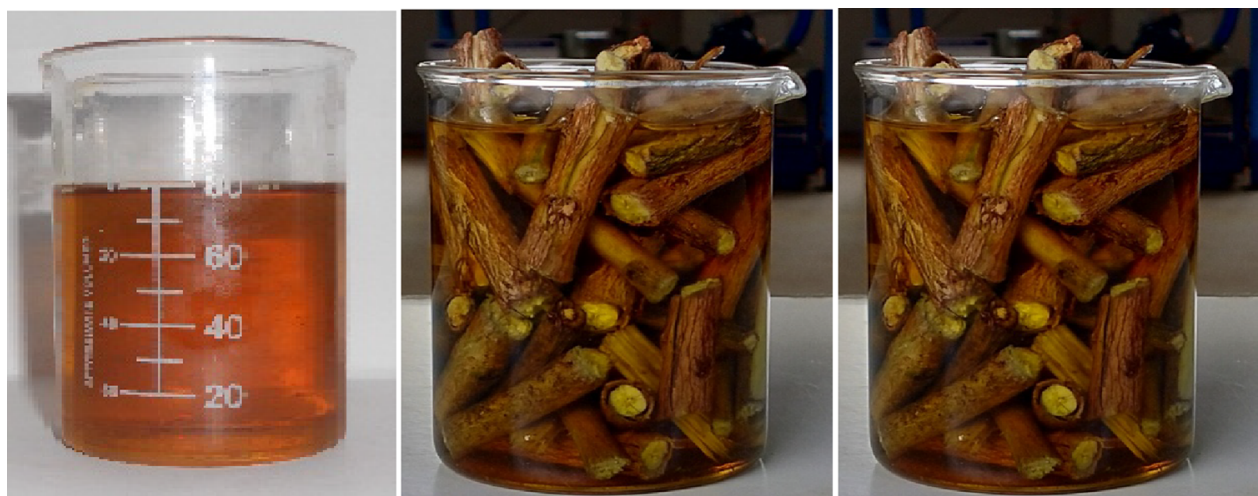

(a) WFO biodiesel (b) Absorption after 1 day

(c) Absorption after 2 days

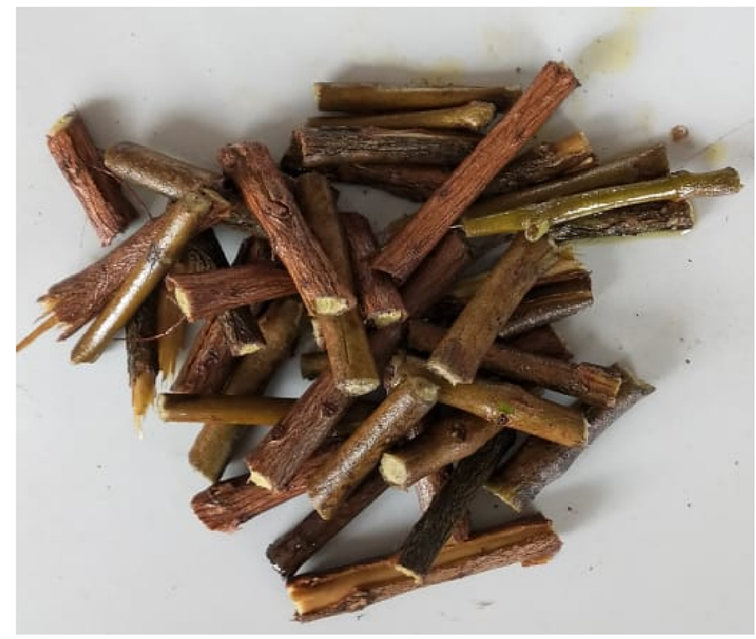

(d) Biodiesel absorbed biomass after 4 days

Table 3 Hydrogen properties [16, 24, 25]

\begin{tabular}{lll}
\hline Sl. no & Properties & Hydrogen \\
\hline 1 & Density of liquid at $20^{\circ} \mathrm{C}, \mathrm{kg} / \mathrm{m}^{3}, 1$ bar & 0.0821 \\
2 & Boiling point $(\mathrm{K})$ & 20.271 \\
3 & Lower calorific value $(\mathrm{kJ} / \mathrm{kg})$ & 119,000 \\
4 & Limits of flammability in air $(\mathrm{vol} . \%)$ & $4.0-75.0$ \\
5 & Auto ignition temperature $(\mathrm{K})$ & 858 \\
6 & Viscosity $\left(1 \mathrm{bar}, 20^{\circ} \mathrm{C}\right)(\mathrm{g} / \mathrm{cm}-\mathrm{s})$ & $8.813 \times 10^{-5}$ \\
7 & Octane number & 130 \\
8 & Flame velocity $(\mathrm{cm} / \mathrm{s})$ & 352 \\
9 & Stoichiometric $\mathrm{A} / \mathrm{F}$ ratio, $\mathrm{kg}$ of air $/ \mathrm{kg}$ of fuel & 34.39 \\
10 & Flame temperature of hydrogen/air $\left({ }^{\circ} \mathrm{C}\right)$ & 2115 \\
\hline
\end{tabular}

analysis. Tail pipe gas composition is consisting of smoke, $\mathrm{HC}, \mathrm{CO}$ and NOx were measured during the steady-state operation using Hartridge smoke meter and five-gas analyzers (A DELTA 1600 S-non dispersive infrared analyzer). Throughout the experiment, engine speed and gas flow rate were fixed constant. However, producer gas quality was changing intermittently with respect to time and load, therefore difficulty was encountered during measurement of gas flow rate. Therefore, for each load, at least ten readings were recorded at different timings and averaged out value is used for the analysis.

It is well known that producer gas derived from MSW has inferior quality leading to poor performance of an engine. In this regard, in the present work, producer gas quality was increased by using biodiesel treated biomass. In addition, quality of fuel combination was enriched with $8 \mathrm{lpm}$ of hydrogen. Initially hydrogen was stored in a high-pressure sealed storage container at 150 bar pressure and room temperature. During the experimentation, hydrogen gas pressure was lowered to 1.5-2 bar by means of two stage gas pressure controller. Then it is bypassed using a shut off valve. A flow regulator was employed in the hydrogen flow line and it controls volume flow rate. Further digitally operated flow meter used in the hydrogen flow line meters correct quantity of flow rate of hydrogen. Also a suitable rotameter was used to ensure the flow rate of hydrogen. 


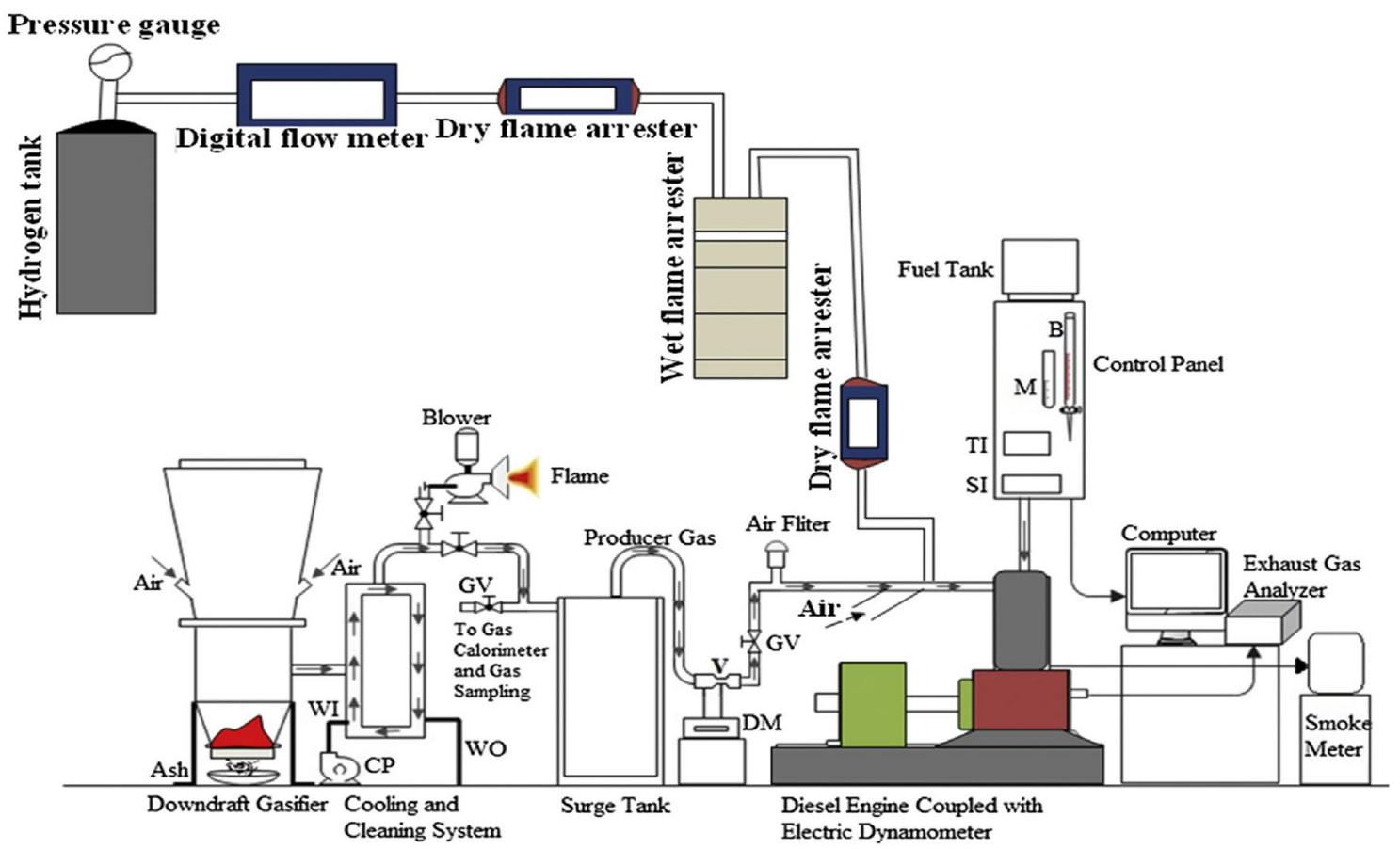

Fig. 2 Experimental set up

Table 4 Specifications of the engine and downdraft gasifier

\begin{tabular}{|c|c|c|c|c|}
\hline \multirow[t]{2}{*}{ SI no } & \multicolumn{2}{|l|}{ Compression ignition engine } & \multicolumn{2}{|l|}{ Down draft gasifer } \\
\hline & Type of engine & $\begin{array}{l}\text { Kirlosker make Single cylinder four } \\
\text { stroke direct injection diesel engine }\end{array}$ & Type & Downdraft gasifier \\
\hline 1 & Nozzle opening pressure & 200-205 bar & Supplier & $\begin{array}{l}\text { Ankur Scientific Energy } \\
\text { Technologies Pvt. } \\
\text { Ltd., Baroda }\end{array}$ \\
\hline 2 & Rated power & 5.2 kW @1500 RPM & Rated capacity & $62,735 \mathrm{~kJ} / \mathrm{h}$ \\
\hline 3 & Bore and Stroke length & 87.5 and $110 \mathrm{~mm}$ & Rated Gas flow & $15 \mathrm{Nm}^{3} / \mathrm{h}$ \\
\hline 4 & Compression ratio & 17.5: 1 & Average gas calorific value & $5-5.6 \mathrm{MJ} / \mathrm{m}^{3}$ \\
\hline 5 & $\begin{array}{l}\text { Arrangement of valves and } \\
\text { Combustion Chamber }\end{array}$ & $\begin{array}{l}\text { Overhead and Open Chamber (Direct } \\
\text { Injection) }\end{array}$ & Rated woody biomass consumption & $5-6 \mathrm{~kg} / \mathrm{h}$ \\
\hline 6 & Displacement Volume & $660 c c$ & Hopper storage capacity & $40 \mathrm{~kg}$ \\
\hline 7 & Dynamometer arm length & $0.180 \mathrm{~m}$ & Typical conversion efficiency & $70-75 \%$ \\
\hline
\end{tabular}

Table 5 Test fuels and engine operating parameters

\begin{tabular}{|c|c|c|c|c|c|c|}
\hline SI. No & Mode of engine operation & Fuel used & IT ('bTDC) & IP (bar) & $C R$ & Nozzle used \\
\hline \multirow[t]{6}{*}{1} & \multirow[t]{6}{*}{ Dual fuel (DF) operation } & Diesel-PG & 27 & 205 & 17.5 & 3 hole, $0.25 \mathrm{~mm}$ dia. \\
\hline & & Diesel-(PG + H2) & & & & \\
\hline & & DiSOME-PG & & 230 & & \\
\hline & & DiSOME- (PG + H2) & & & & \\
\hline & & B20-PG & & & & \\
\hline & & $\mathrm{B} 20-(\mathrm{PG}+\mathrm{H} 2)$ & & & & \\
\hline
\end{tabular}


An appropriate mixing chamber was employed to mix hydrogen with an air-producer gas mixture. After all, mixture of air-producer gas -hydrogen is permitted into the engine cylinder through intake manifold of the engine. In addition, flame arrestors (dry and wet type) are used in the hydrogen flow line and they operate as non-return valve, hence any backfire and fire hazard risk caused by the back flow of hydrogen is prevented.

Present work involves dual fuel engine operation with dairy scum oil biodiesel and Producer gas enriched with fixed mass flow rate of hydrogen (8 lpm). However as far as the gaseous fuels are considered, the producer gas is enriched using Hydrogen. However, Hydrogen flow rate is fixed and mass of producer gas coming from the downdraft gasifier to the engine manifold varies due to varied quality of the gas generated within the gasifier as it has different composition of $\mathrm{CO}, \mathrm{CH}_{4}, \mathrm{H}_{2}$ and inert gas. For fixed injection timing, mass of fuel injected remains constant. The mass of pilot fuel is injected directly into the producer gas-hydrogen mixture at the end of compression stroke $\left(27^{\circ} \mathrm{bTDC}\right)$. The quantity of the injected fuel was varied with respect to different engine loads. Present work mainly focuses on higher utilization of gaseous fuels and accordingly the pilot fuel quantity injected is kept constant that can ensure combustion of the fuels inducted as well as injected. The pilot fuel injection can be adjusted, but minimum quantity is essential to initiate the combustion and to the point, pilot fuel was adjusted.

In the beginning of the experiment, diesel engine was started with diesel/DiSOME biodiesel and then hydrogen-producer gas mixture was inducted into the engine cylinder along with air. In this experimental operation, hydrogen flow rate was limited to $8 \mathrm{lpm}$ because of safety and to prevent knocking and any hazardous incident. In this present study, the producer gas was aspirated naturally and mixed with air using parallel flow gas entry carburetor shown in Fig. 2a. Hydrogen was then blended with air-producer gas mixture using a suitable venture and finally air-producer gas-hydrogen mixture was admitted into the engine cylinder. The carburator or venture has 6 holes, each having $0.6 \mathrm{~mm}$ diameter and was employed in the intake manifold at $300 \mathrm{~mm}$ length from the inlet port shown in Fig. $2 \mathrm{~b}$. Figure 2c presents the venture used for hydrogen mixing with air-producer gas mixture. Mixing chamber and venture installation in the experimental set up made during the work is presented in Fig. 2d. Finally the data measured for the DiSOME-producer gas derived from biodiesel treated biomass, with and without hydrogen addition were distinguished and compared to that of base line diesel based dual fuel operation.

\section{Results and discussions}

In this section trial tests were conducted to evaluate the influence of biodiesel treated biomass and hydrogen properties on the combustion and emission characteristics of a diesel engine operated on dual fuel mode using various fuel combinations. In this current work, hydrogen flow rate was maintained constant (8 lpm). Engine operating conditions were presented in Table 5. Readings were recorded for different engine loading conditions. Finally the outcome for the DiSOME-producer gas derived from biodiesel treated biomass, with and without hydrogen addition was distinguished and compared to the base line diesel based dual fuel operation and the same was demonstrated in the successive paragraphs.

\subsection{Performance parameters}

Disparities of brake thermal efficiency (BTE) with different fuel combinations are illustrated in Fig. 3. For the same producer gas induction, dual fuel operation with and without hydrogen, diesel based operation provided amplified BTE than DiSOME and its blended fuel based dual fuel operation. This could be credited to differences in the fuel properties. However, diesel based dual fuel operation with hydrogen addition marginally provided greater BTE by $3.01 \%$ than the same diesel based duel fuel operation without hydrogen addition. It may be caused by the fact that complete combustion of the diesel-producer gas with hydrogen. It could also be the fact that both injected and inducted fuel properties that have a greater impact on the performance characteristics. Further, lean limit of

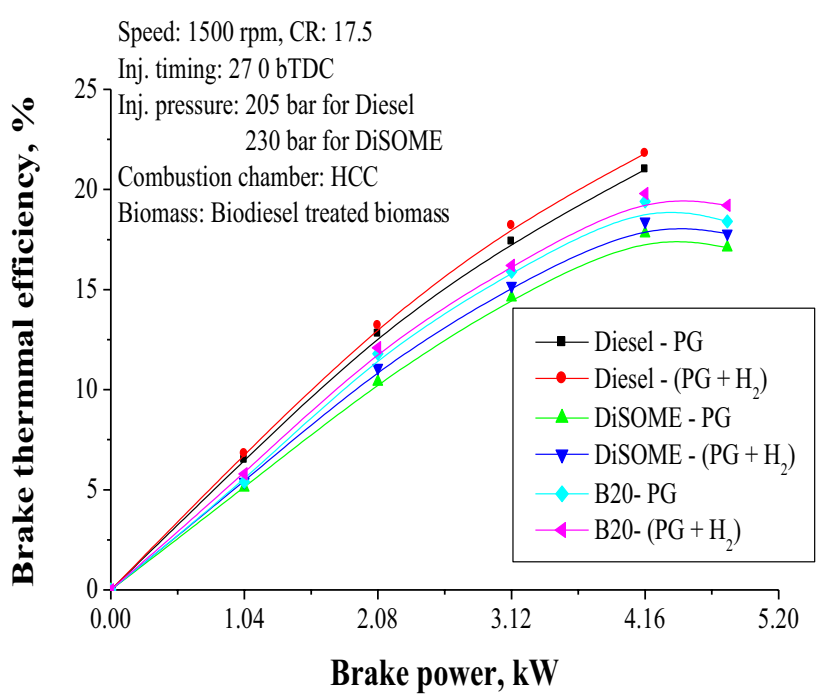

Fig. 3 Variation of brake thermal efficiency with hydrogen addition 
hydrocarbon fuels may increase with addition of small quantity of hydrogen and homogeneity of fuel combination before combustion. In addition oxygen reaching ability increases due to greater diffusion co-efficient of hydrogen which in turn leads to better combustion [26]. It is noticed that diesel-producer gas operation with and without hydrogen resulted in audible noise due to lean mixture formation and increased in-cylinder pressure. Therefore, Diesel based dual fuel operation with and without hydrogen addition was not operated beyond $80 \%$ load. Results showed that DiSOME and blended fuel with producer gas and hydrogen provided improved thermal efficiency by $3.6 \%$ and $4.1 \%$ respectively at $80 \%$ load compared to the operation without hydrogen addition due to higher calorific value gas utilizes in built oxygen of biodiesel leading to better mixture formation. In addition higher flame velocity of hydrogen enhances the combustion rate and helps to spread the flame entire combustion chamber [16, 21]. In addition, broader flammability boundary of hydrogen helps to burn lean mixture. But calorific value and flame velocity of both biodiesel and producer gas being very low leads to decreased thermal efficiency compared to diesel based dual fuel operation. Further, hydrogen addition lowers the quenching distance. This quenching distance refers to the distance from the internal cylinder wall to where the combustion flame extinguishes. Quenching distance will be reduced if hydrogen addition was done. Combustion difficulties caused by long and narrow combustion chamber and long quenching distance of engine can be solved by hydrogen addition. However, B20-producer gas combination resulted in marginally better thermal efficiency than DiSOME based dual fuel operation due to improved properties of blended fuel. Further, it is observed that decreased power derating with hydrogen addition to biodiesel/blended fuel and producer gas combination leads to operate the engine more than $80 \%$ load. With DiSOME-producer gas combination without hydrogen addition provided lower thermal efficiency due to retarding of combustion rate caused by the lower energy density of biodiesel and producer gas, higher viscosity, lower energy content and lower volatility of biodiesel and CO content of producer gas may affect the performance negatively. In addition mixture inhomogeniety may also be the reason for the observed trend. Hence dual fuel operation with biodiesel and producer gas combination, the energy from fuel may not be efficiently converted into mechanical work.

Exhaust gas temperature (EGT) variation with respect to brake power for different fuel combinations are demonstrated in Fig. 4. Results showed that diesel-producer gas combination with and without hydrogen addition resulted in comparatively lower EGT than biodiesel based dual fuel operation. This could be credited to the

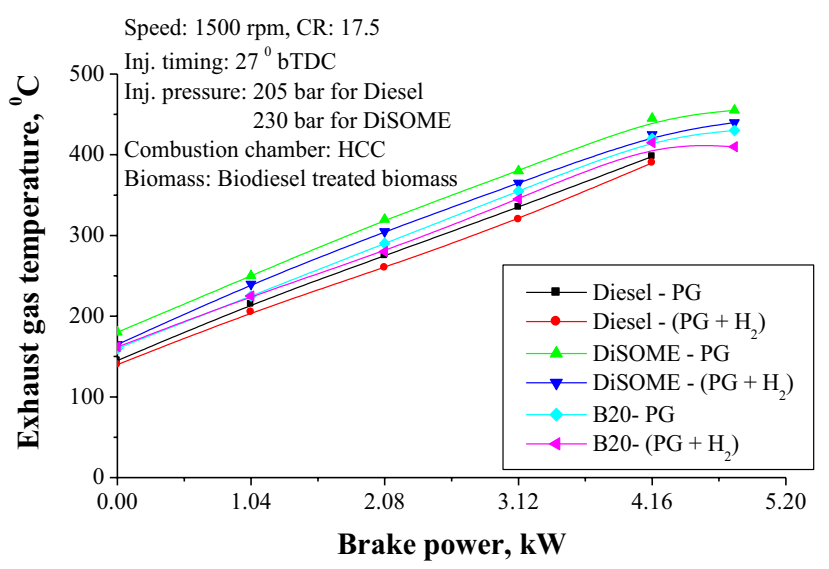

Fig. 4 Variation of exhaust gas temperature with hydrogen addition

incomplete burning of the biodiesel-producer gas combination during premixed combustion phase caused by the variations in the fuel properties and composition. However, for the same diesel-producer gas operation with hydrogen addition provided marginally lower EGT by $3.1 \%$ than the diesel based operation without hydrogen addition. This may be due to increased burning of the fuel combination during rapid combustion phase caused by the increased flame velocity of the fuel combination. Further, results with DiSOME and blended fuel with producer gas and hydrogen showed that reduced EGT by $4.6 \%$ and $2.1 \%$ respectively at $80 \%$ load compared to the operation without hydrogen addition. Presence of hydrogen in the fuel combination increases the flame temperature; this in turn leads to better burning of the fuel combination [16]. However, B20-producer gas combination resulted in marginally reduced EGT than DiSOME based dual fuel operation due to improved properties of blended fuel leading increased premixed combustion. With DiSOME-producer gas combination without hydrogen addition provided amplified EGT due to amplified burning rate of fuel combination during diffusion combustion phase caused by inferior properties of both biodiesel and producer gas. In addition, during dual fuel operation part of the air was replaced by the producer gas and hydrogen combination. Therefore amount of air admitted into the engine was reduced. However, diesel engine requires extra air for complete combustion. But, biodiesel oxygen content cannot fulfill the need completely. Amplified EGT for DiSOME-producer gas operation could also be due to presence of $\mathrm{CO}$ in the producer gas and inhomogeinity of fuel combination with air, lowered air-fuel ratio and differences in the fuels properties can lead to burn the fuel combination during diffusion combustion phase. Hence dual fuel operation with biodiesel and producer gas combination 
without hydrogen addition, the fuel energy may not burn completely during earlier stages of combustion.

\subsection{Emission parameters}

The emission characteristics of a diesel engine are lowered by the use of dual fuel concept. Engine out exhaust composition reflects the combustion quality. Various emission levels of dual fuel engine under a steady state conditions were measured using calibrated instruments. The various emission levels during dual-fuel mode of operation are discussed in the subsequent section.

Figure 5 shows decreased smoke emission levels with addition of hydrogen. For the same producer gas induction, diesel based operation with hydrogen results into lower smoke levels compared to the same fuel combination without hydrogen addition. Similarly, DiSOME and B20 based operation with producer gas and hydrogen resulted into reduced smoke levels compared to same fuel combinations tested without hydrogen addition. As the flame speed and flammability limit of hydrogen is superior leading to amplify combustion pressure and temperature, this in turn can burn fuel combination faster. In addition, it could be credited to the fact that hydrocarbon fuels lean limit may increase when small amount of hydrogen is added and greater diffusion co-efficient of hydrogen enhances homogeneity of mixture before combustion and also increases oxygen reaching ability which in turn leads to better combustion with reduced smoke levels [26]. Further, fuel composition is having low proportion of pilot fuel, and hydrogen has zero carbon, this may also be responsible for the reduced smoke levels in the exhaust. As far as biodiesel and blended fuel based operation is concerned, B20-producer gas combination resulted in marginally reduced smoke levels than DiSOME based dual fuel operation due to improved properties of blended fuel

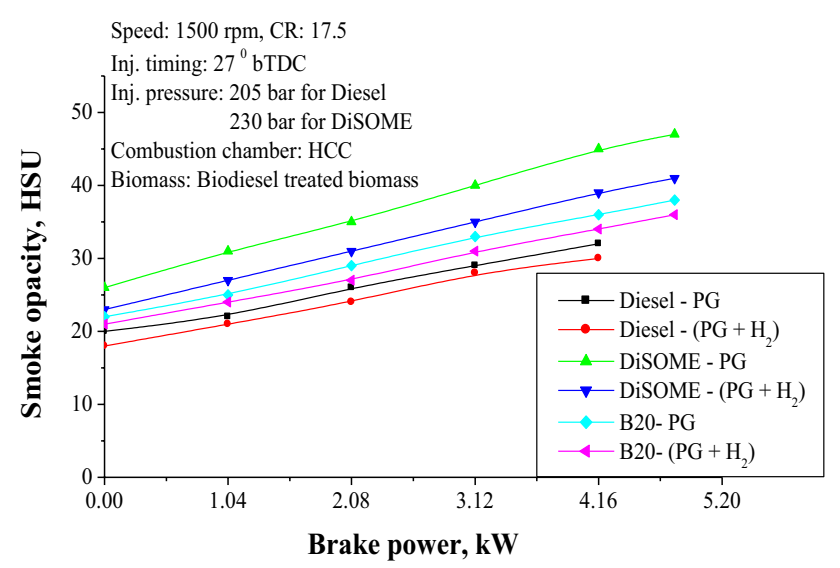

Fig. 5 Variation of smoke opacity with hydrogen addition leading lower smoke levels caused by the improved combustion. With DiSOME-producer gas combination without hydrogen addition provided amplified smoke levels due to retarded burning rate of fuel combination caused by inferior properties of both biodiesel and producer gas. In addition, $\mathrm{CO}$ content of producer gas may hinder the oxidation leading to affect the combustion negatively. Hence dual fuel operation with biodiesel and producer gas combination without hydrogen addition, the fuel combination may not burn completely leading to increase smoke levels.

$\mathrm{HC}$ and $\mathrm{CO}$ emission levels for different fuel combinations are displayed in Figs. 6 and 7. For the same producer gas induction, diesel, DiSOME and B20 based due fuel operation with hydrogen addition resulted in marginally lower $\mathrm{HC}$ and $\mathrm{CO}$ emissions compared to the respective fuel combinations without hydrogen addition. Results showed that diesel based dual fuel operation with and

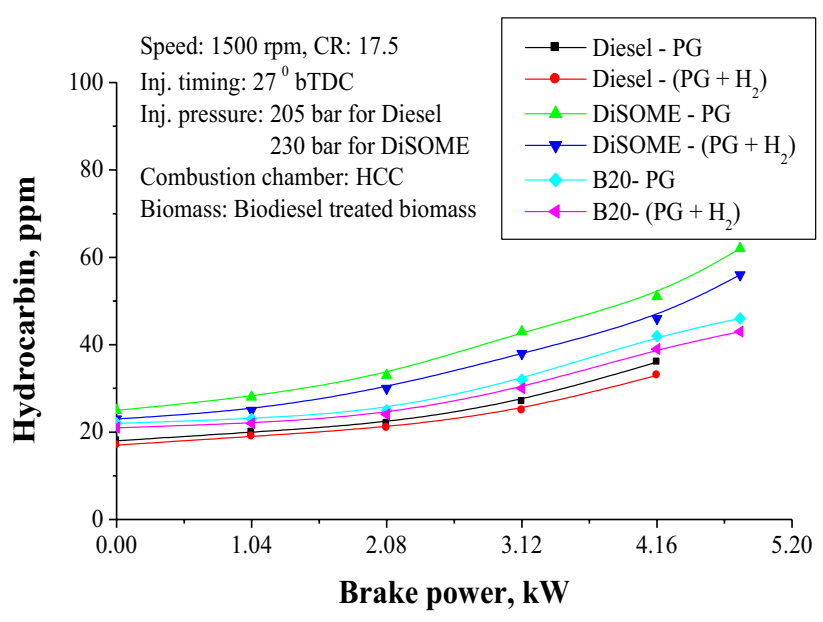

Fig. 6 Variation of hydrocarbon with hydrogen addition

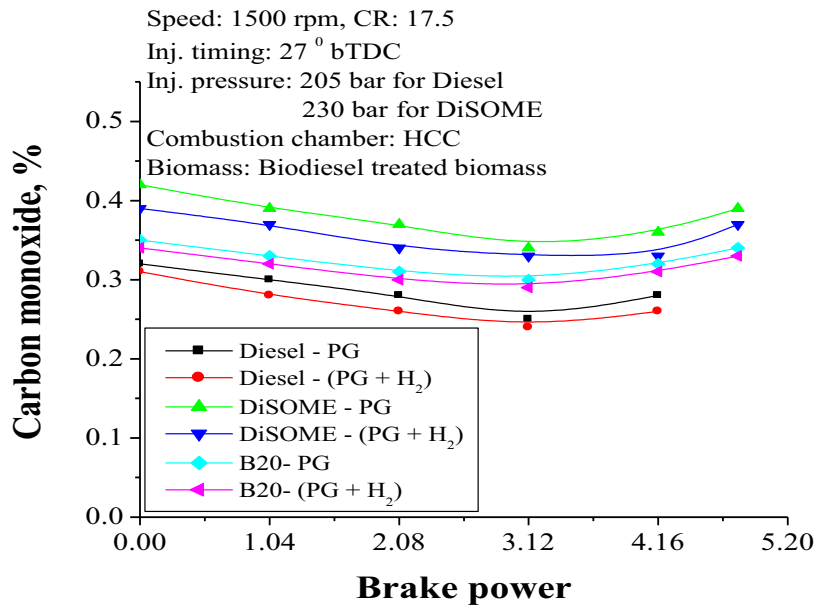

Fig. 7 Variation of carbon monoxide with hydrogen addition 
without hydrogen addition provided marginally lower $\mathrm{HC}$ and $\mathrm{CO}$ emissions compared to biodiesel based dual fuel operation. This could be credited to the incomplete combustion due to incomplete mixing and poor oxidation caused by the inadequate atomization caused by the high content of long chain fatty acids present in the DiSOME and $\mathrm{B} 20$. In addition, lower adiabatic flame temperature of producer gas, greater viscosity of biodiesels, lower calorific value of DiSOME and B20 and producer gas and slowburning nature of producer gas are also accountable for the observed trend. Also, fuel properties of biodiesel and producer gas have major influence on the emission levels which in turn leads to inadequate oxidation of biodiesel due to deficient availability of oxygen for combustion. However, $\mathrm{CO}$ content of producer gas plays very important role during combustion of biodiesel, which amplifies incomplete combustion of DiSOME and B20-producer gas combination. However, reduced equivalence ratio is responsible for higher $\mathrm{CO}$ emissions during dual fuel operation. In addition, higher CO content was observed in the exhaust at partial load. It could be due to lower combustion temperature and lean mixture formation. As far as biodiesel is concerned, DiSOME and B20 based dual fuel operation with hydrogen addition and at $80 \%$ load, provided $9.6 \%$ and $6.4 \%$ reduced $\mathrm{HC}$ emissions compared to the operation without hydrogen addition. Similarly, CO levels were lowered marginally by $5.45 \%$ and $3.2 \%$ compared to the operation without hydrogen addition. This is because hydrogen addition improves combustion of leaner mixture. Hydrogen addition amplifies combustion temperature, flame velocity and flame flammability limit which in turn helps to improve the burning rate of fuel combination. Hydrogen addition improves the lean limit of hydrocarbon fuels and homogeneity of fuel combination before combustion and increases oxygen reaching ability

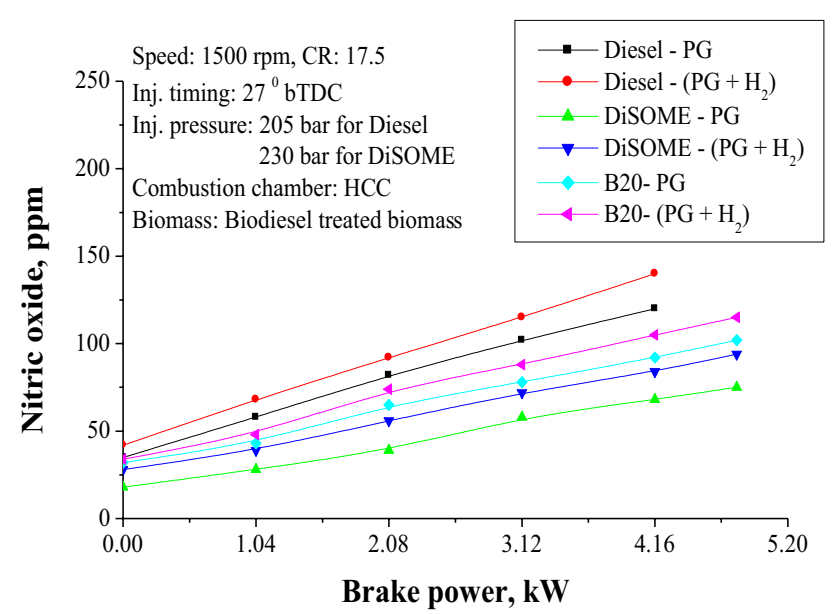

Fig. 8 Variation of nitric oxide with hydrogen addition due to greater diffusion co-efficient of hydrogen which in turn leads to better combustion [26]. Therefore, with hydrogen addition both $\mathrm{HC}$ and $\mathrm{CO}$ levels were reduced.

Nitric oxide (NOx) emission levels with respect to brake power for various fuel combinations with and without addition of hydrogen are presented in Fig. 8. For the same producer gas induction, results showed that diesel based dual fuel operation with hydrogen provided amplified NOx levels compared to the biodiesel based fuel combination. This could be credited to improved pre-mixed combustion phase caused by differences in the chemical energy supplied to the engine. However, addition of hydrogen, DiSOME and B20 based operation with producer gas resulted in amplified NOx levels by $19.6 \%$ and $12.8 \%$ compared to other biodiesel based fuel combinations without hydrogen addition. As the flame speed and flammability limit of hydrogen is superior leading to amplify combustion pressure and temperature. Further greater diffusion coefficient of hydrogen improves the oxygen reaching ability and enhances homogeneity of mixture; this can burn fuel combination faster [26]. Further, the fuel combination becomes leaner with gaseous fuel leading to enhance ignition delay which in turn increases the cylinder pressure. As far as biodiesel and blended fuel based operation is concerned, B20-producer gas combination resulted in amplified NOx levels than DiSOME based dual fuel operation due to improved properties of blended fuel leading to increased NOx levels caused by the improved combustion rate. With DiSOME-producer gas combination with hydrogen addition provided amplified NOx levels due to advanced burning rate of fuel combination caused by increased combustion rate. Hence dual fuel operation with biodiesel and producer gas combination without hydrogen addition, the fuel combination may not burn completely leading to decrease NOx levels in the exhaust.

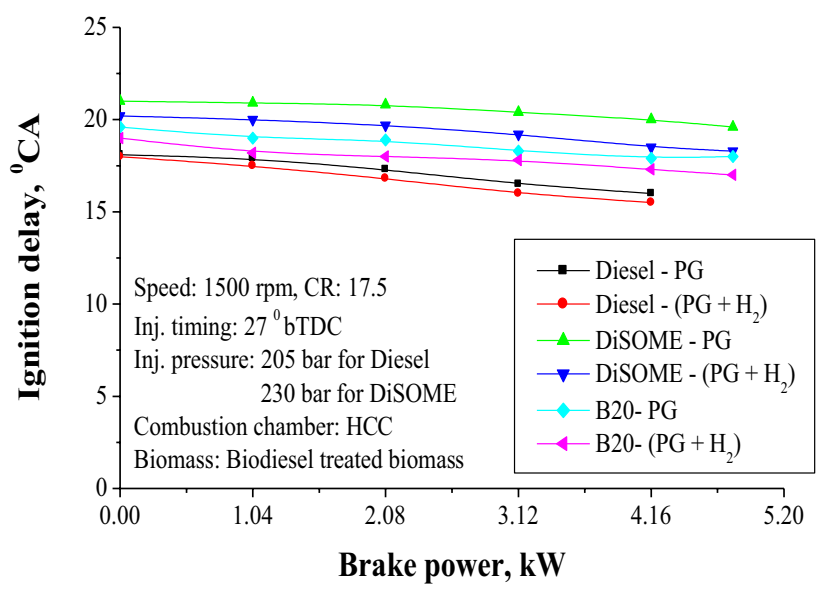

Fig. 9 Variation of ignition delay with hydrogen addition 


\subsection{Combustion characteristics}

The variations in ignition delay (ID) with brake power for different fuel combinations are presented in Fig. 9. The ID is determined based on the static injection timing. ID during dual fuel operation contains three parts, which are pilot fuel ignition, producer gas ignition and hydrogen ignition. Decreased ID has been observed with increase in brake power for all fuel combinations tested. This could be credited to increased cylinder gas pressure and temperature caused by the enhanced quantity of fuel burning. From Fig. 9 and at the identical operating circumstances, diesel-producer gas combination with hydrogen addition showed decreased ignition delay compared to other fuel combinations at $80 \%$ load. This may be credited to the better combustion properties diesel fuel. This in fact results into lower ID for diesel-producer gas operation. Similarly DiSOME and B20 based dual fuel operation with hydrogen addition resulted in reduced ID by $6.8 \%$ and $3.8 \%$ compared to the same fuel combination without hydrogen addition. This could be credited to the fact that producer gas supply being same, but hydrogen addition makes the differences in ID. This may be because hydrogen has greater diffusivity. Therefore this has a capability to disperse and mixes with fuel combination very easily. In addition, hydrogen facilitates the better homogeneity of fuel and air. This feature may enhance the chemical kinetics and lowers the chemical delay. Therefore, thermal efficiency drop caused by the greater viscosity and low energy density fuel combination can be amplified using hydrogen addition. Further, results showed that B20-producer gas combination resulted in lower ID by $3.1 \%$ than DiSOME-producer gas-hydrogen combination due to presence of diesel fuel in the fuel combination. This may be due to differences in the fuel properties. It is noticed that DiSOME-producer gas combination showed greater ID

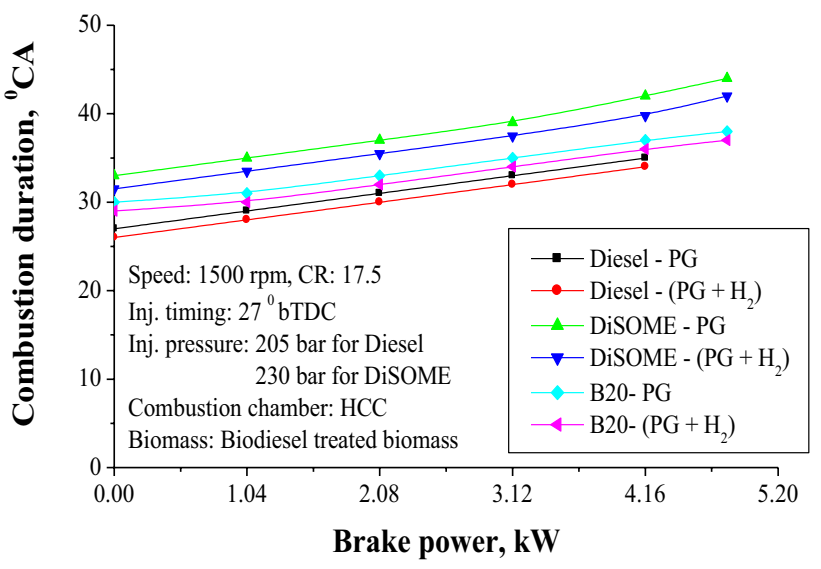

Fig. 10 Variation of combustion duration with hydrogen addition than other fuel combinations due to inferior properties of both DiSOME and producer gas.

Figure 10 demonstrate the influence of brake power on combustion duration (CD) for various fuel combinations with and without hydrogen addition. CD was determined as the time period between the combustion start (SOC) and $90 \%$ cumulative heat release. CD was amplified with increase in power output caused by the increase in the quantity of fuel injected. For the identical operating circumstances, CD was found to be lower for diesel-producer gas combination with hydrogen addition compared to the operation with other fuel combinations at $80 \%$ load. Similarly, hydrogen addition for DiSOME and B20 based dual fuel operation provided lower CD by $5.2 \%$ and $3.1 \%$ compared to the operation with same fuel combination without hydrogen addition. This is credited to greater flame speed of fuel combination caused by the hydrogen addition. Hydrogen has lower ignition energy leading to burn the fuel combination very fast. In addition greater diffusivity character of hydrogen enhances mixture quality caused by the better dispersion in the air-producer gas mixture. In addition, hydrogen has smaller quenching distance, hence flame produced can travel throughout the combustion chamber before it quenches. Further, results showed that B20-producer gas combination resulted in lower CD by $9.8 \%$ than DiSOME-producer gas-hydrogen combination due to presence of diesel fuel in the fuel combination. This may be due to differences in the pilot injected fuel properties. It is noticed that DiSOME-producer gas combination showed greater $C D$ than other fuel combinations due to inferior properties of both DiSOME and producer gas. This may also be credited to the fact that dual fuel operation with DiSOME-producer gas operation without hydrogen addition provided a second peak during a diffusion-oxidation phase caused by the reduced air-fuel mixing rates along with slow-burning producer gas and the greater viscosity of DiSOME. However, improved heat release rate was attained when hydrogen was added. It can be concluded that, in the case of dual fuel operation with hydrogen enrichment, energy released by hydrogen leads to better combustion along with producer gas and which in turn lowers $C D$ comparatively.

The variation of in-cylinder pressure with respect to crank angle at $80 \%$ load for different fuel combinations with and without hydrogen addition is presented in Fig. 11. Hydrogen addition being same, increased cylinder pressure was observed for diesel-producer gas combination compared to other fuel combinations tested. Similarly, DiSOME and B20 based dual fuel operation with hydrogen addition provided amplified in-cylinder pressure compared to the same fuel combinations without hydrogen addition. This could be credited to superior properties of hydrogen which in turn leads to 


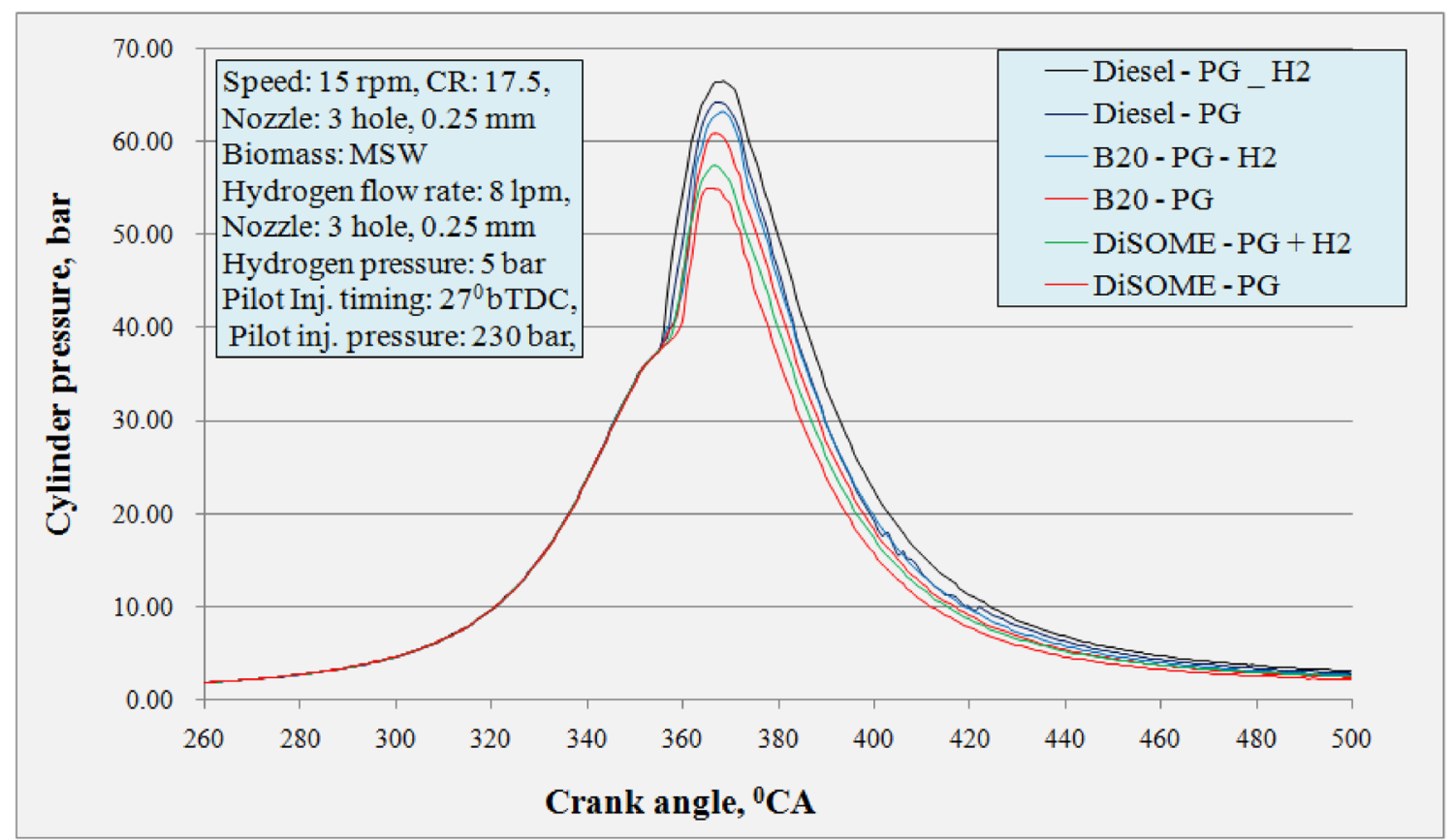

Fig. 11 Variation of cylinder pressure with crank angle for various fuel combination at $80 \%$ load with hydrogen addition

better mixture homogeneity, increased flame velocity and lean mixture combustion. Increase in cylinder pressure depends on the amount of fuel utilized during the un-controlled combustion period. Also, it depends on the mixture preparation during ID, which decides the combustion. Greater diffusion coefficient of hydrogen increases reachability of oxygen, this in turn provides uniform combustible mixture before combustion. Hydrogen addition in the fuel combination amplifies laminar flame speed linearly $[24,26]$. Therefore, both in-cylinder pressure and heat release rate were increased almost linearly with hydrogen content in low energy content gas. Higher auto-ignition temperature of hydrogen causes rapid combustion resulting into improved combustion of fuel combination. Hydrogen being same, results showed that DiSOME - producer gas and B20-producer gas operation provided lower cylinder pressure by $8.6 \%$ and $4.6 \%$ respectively compared to diesel based operation at $80 \%$ load. As far as biodiesel based dual fuel operation is concerned, biodiesel based dual fuel operation provided second peak in the diffusion combustion phase compared to diesel-producer gas and B20-producer gas operation. Inadequate quality of DiSOME, reduced air entrainment and mixture quality together with the slowburning nature of producer gas and decreased cetane number of fuel combination caused by both hydrogen and producer gas are main reasons for such observed trend of results with DiSOME and B20 based dual fuel operation.
Figure 12 demonstrate the heat release rate (HRR) for various fuel combinations with and without hydrogen addition at $80 \%$ load. HRR was amplified with increase in the quantity of pilot fuel injected. For the identical operating circumstances, HRR was found to be greater for dieselproducer gas combination with hydrogen addition compared to the operation with other fuel combinations at $80 \%$ load. Similarly, hydrogen addition for DiSOME and B20 based dual fuel operation provided amplified HRR by $5.2 \%$ and $3.1 \%$ compared to the operation with same fuel combination without hydrogen addition. This is credited to the fact that superior properties of hydrogen amplify the mixture homogeneity caused by the better oxygen reachability due to diffusivity character of hydrogen, increased flame speed of fuel combination caused by the hydrogen addition are responsible for the observed trend. Another possible reason is that, hydrogen has smaller quenching distance; hence the flame produced can enhance un-controlled combustion phase due to faster flame travel throughout the combustion chamber before it quenches. Further, for the same hydrogen addition, results showed that B20-producer gas combination resulted in amplified HRR than DiSOME-producer gas combination due to presence of diesel fuel in the fuel combination. This could also be due to differences in the pilot fuel used and it causes to decrease HRR for biodiesel based dual fuel combination. Further this tendency increases burning of fuel combination in the later stages and produces second peak in the diffusion combustion phase. However, reduced 


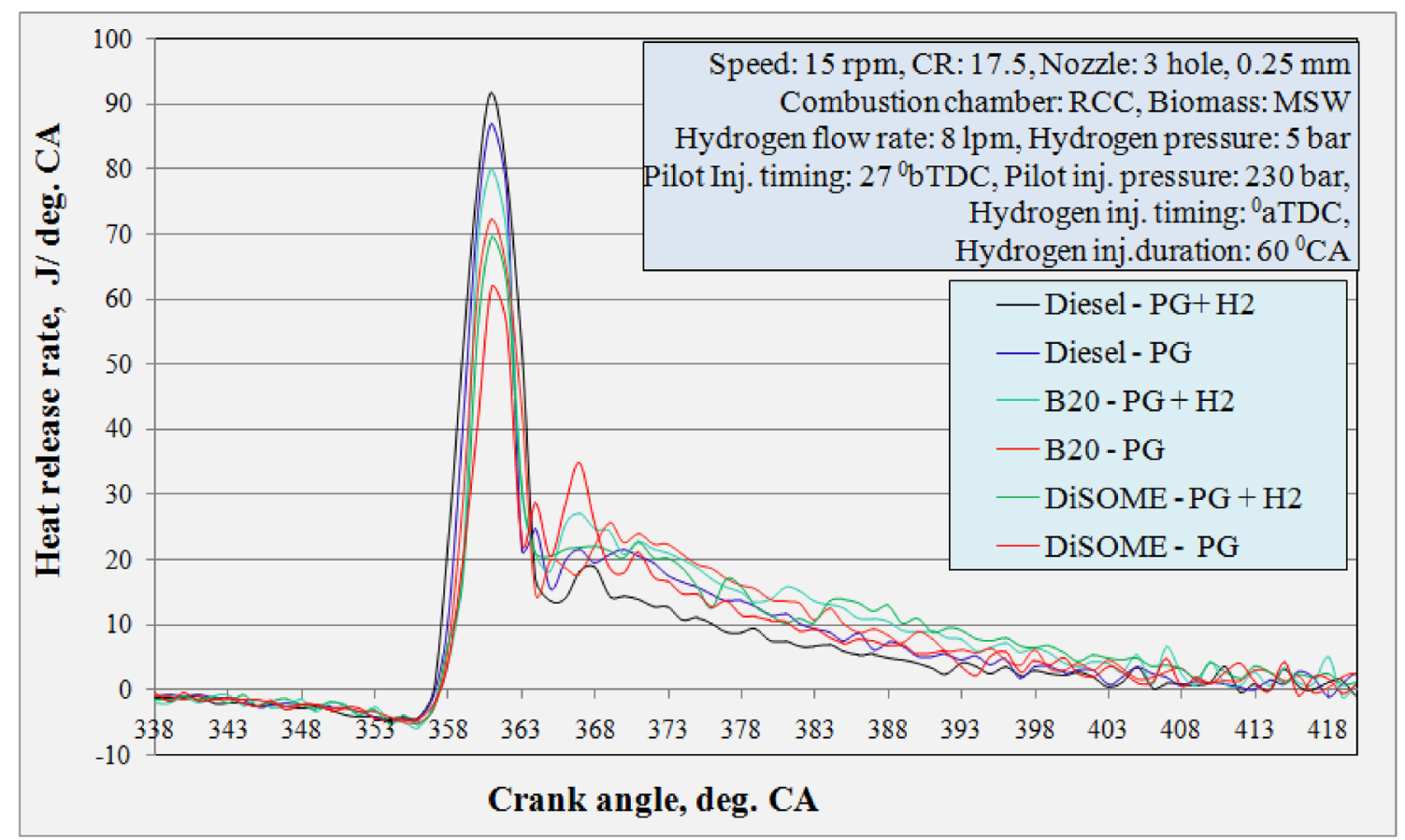

Fig. 12 Variation of heat release rate with crank angle for various fuel combination at $80 \%$ load with hydrogen addition

air-fuel mixing rates along with slow-burning producer gas, and greater viscosity of DiSOME are accountable for the reduced HRR for DiSOME-producer gas combination. Results showed that improved heat release rate when hydrogen was added to DiSOME-producer gas combination. It can be concluded that, in the case of dual fuel operation with hydrogen enrichment, energy released by hydrogen leads to increased HRR along with producer gas.

\section{Conclusions}

In the present work, utilization of dairy scum, vegetable oil and MSW derived fuels (DiSOME/B20-producer gas combination) in a diesel engine operating on dual fuel mode with and without hydrogen has been investigated. Use of waste frying oil treated biomass increases the energy content of the biomass. Fuel combinations selected for the engine study are being renewable in nature and provide freedom in controlling fuel substitution ratio. Based on the results obtained, DiSOME/B20-producer gas operation with constant $8 \mathrm{Ipm}$ of hydrogen provide amplified thermal efficiency by $3.6 \%$ and $4.1 \%$ respectively at $80 \%$ load compared to the DiSOME-producer gas operation. However, for the same hydrogen addition, DiSOME-producer gas and B20-producer gas operation provided $13.2 \%$ and $8.9 \%$ decreased thermal efficiency compared to the dieselproducer gas operation.
On an average, for the same hydrogen induction and with optimized engine parameters, DiSOME/ B20-producer gas operation provided $23.2 \%$, and $14.4 \%$ decreased smoke, $30.2 \%$, and $25.4 \%$ decreased HC, $21.4 \%$, and $16.2 \%$ decreased CO, and $38.6 \%$, and $26.2 \%$ increased NOx levels compared to the same fuel combination without addition of hydrogen at $80 \%$ load. Dual fuel operation provide 5-8\% decreased power derating, $55.8-66.4 \%$ pilot fuel saving and smoother engine operation. For the same hydrogen induction, DiSOME/B20-producer gas operation provided $8.6 \%$ and $4.6 \%$ increased cylinder pressure, and $5.2 \%$ and $3.1 \%$ increased HRR compared to the same fuel combinations without hydrogen at $80 \%$ load.

Further, this present work is limited to use generated producer gas from down draft gasifier for power generation applications. Purification of producer gas is not addressed. Future developments concern about cracking of tar and reducing nitrogen from producer gas. In addition, optimization of producer gas fuelled dual fuel engine in terms of performance and emissions by using additional air or supercharger for a diesel engine to obtain better results.

Acknowledgements I thank Mr. S.S. Halewadimath, Assistant professor, Department of Mechanical Engineering, KLE Institute of Technology, Hubli for his kind help to carry out this research work. 


\section{Compliance with ethical standards}

Conflict of interest Authors have no conflict of interest.

Open Access This article is licensed under a Creative Commons Attribution 4.0 International License, which permits use, sharing, adaptation, distribution and reproduction in any medium or format, as long as you give appropriate credit to the original author(s) and the source, provide a link to the Creative Commons licence, and indicate if changes were made. The images or other third party material in this article are included in the article's Creative Commons licence, unless indicated otherwise in a credit line to the material. If material is not included in the article's Creative Commons licence and your intended use is not permitted by statutory regulation or exceeds the permitted use, you will need to obtain permission directly from the copyright holder. To view a copy of this licence, visit http://creativecommons .org/licenses/by/4.0/.

\section{References}

1. Banapurmath NR, Tewari PG, Hosmath RS (2008) Performance and emission characteristics of a DI compression ignition engine operated on Honge, Jatropha and sesame oil methyl esters. Renew Energy 33(9):1982-1988. https://doi.org/10.1016/j.renen e.2007.11.012

2. Yaliwal VS, Banapurmath NR, Gireesh NM, Tewari PG (2014) Production and utilization of renewable and sustainable gaseous fuel for power generation applications: a review of literature. Renew Sustain Energy Rev 34:608-627. https://doi.org/10.1016/j. rser.2014.03.043

3. Rajkumar J, Sirajuddin A (2016) Status and challenges of municipal solid waste management in India: a review, environmental chemistry, pollution and waste management-review article. Cogent Environmental Science 2:1-18. https://doi.org/10.1080/23311 843.2016.1139434

4. Isher JA, Utkarsh P (2018) Solid Waste Management in India: An Assessment of Resource Recovery and Environmental Impact. Indian council for research on international economic relations, pp 1-33. http://hdl.handle.net/11540/8143

5. Gunfeel M, Yonggyu L, Kyonam C, Dongsoo J (2010) Emission characteristics of diesel, gas to liquid, and biodiesel-blended fuels in a diesel engine for passenger cars. Fuel 89:3840-3846. https://doi. org/10.1016/j.fuel.2010.07.009

6. Varatharajan K, Cheralathan M (2012) Influence of fuel properties and composition on NOx emissions from biodiesel powered diesel engines: a review. Renew Sustain Energy Rev 16(6):3702-3710. https://doi.org/10.1016/j.rser.2012.03.056

7. Pankaj S, Tikendra NV (2020) Effect of fuel injection pressure on the characteristics of $\mathrm{Cl}$ engine fuelled with biodiesel from Roselle oil. Fuel 265:117005. https://doi.org/10.1016/j.fuel.2019.117005

8. Vivek WK, Kriplani VM (2016) Effect of nano-fluid additives on performances and emissions of emulsified diesel and biodiesel fueled stationary $\mathrm{Cl}$ engine: a comprehensive review. Renew Sustain Energy Rev 59:1338-1348. https://doi.org/10.1016/j. rser.2016.01.051

9. Kavitha V, Geetha V, Jennita Jacqueline P (2019) Production of biodiesel from dairy waste scum using eggshell waste. Process Saf Environ Prot 125:279-287. https://doi.org/10.1016/j. psep.2019.03.021

10. Krishnamurthy KN, Sridhara SN, Ananda Kumar CS (2020) Optimization and kinetic study of biodiesel production from Hydnocarpus wightiana oil and dairy waste scum using snail shell $\mathrm{CaO}$ nano catalyst. Renewable Energy 146:280-296. https://doi. org/10.1016/j.renene.2019.06.161
11. Sivakumar P, Anbarasu K, Renganathan S (2011) Bio-diesel production by alkali catalyzed transesterification of dairy waste scum. Fuel 90(1):147. https://doi.org/10.1016/j.fuel.2010.08.024

12. Soudagar MEM, Nik-Nazri N-G, Kalam MA, Badruddin IA, Banapurmath NR, Yunus Khan TM, Nasir Bashir M, Akram N, Farade R, Afzal A (2019) The effects of graphene oxide nanoparticle additive stably dispersed in dairy scum oil biodiesel-diesel fuel blend on $\mathrm{Cl}$ engine: performance, emission and combustion characteristics. Fuel 257:116015. https://doi.org/10.1016/j.fuel.2019.116015

13. Manjunath $C$ (2020) Comparative study of baseline and modified engine performance operated with dairy scum biodiesel and BioCNG. Renewable Energy 151:604-618. https://doi.org/10.1016/j. renene.2019.11.062

14. Pisarn S, Prachasanti T, Kulachate P (2013) Effect of pilot fuel quantity on the performance and emission of a dual producer gas-diesel engine. Energy Procedia 34:218-227. https://doi.org/10.1016/j. egypro.2013.06.750

15. Swarup KN, Purna CM (2019) Combustion characteristics, performances and emissions of a biodiesel-producer gas dual fuel engine with varied combustor geometry. Energy 168:585-600. https://doi.org/10.1016/j.energy.2018.11.116

16. Yaliwal VS, Banapurmath NR, Gireesh NM, Hosmath RS, Teresa D, Tewari PG (2016) Effect of nozzle and combustion chamber geometry on the performance of a diesel engine operated on dual fuel mode using renewable fuels. Renewable Energy 93:483-501. https ://doi.org/10.1016/j.renene.2016.03.020

17. Harmanpreet S, Mohapatra SK (2018) Production of producer gas from sugarcane bagasse and carpentry waste and its sustainable use in a dual fuel $\mathrm{Cl}$ engine: a performance, emission, and noise investigation. J Energy Inst 91(1):43-54. https://doi. org/10.1016/j.joei.2016.11.002

18. Banapurmath NR, Tewari PG (2009) Comparative performance studies of a 4-stroke $\mathrm{Cl}$ engine operated on dual fuel mode with producer gas and Honge oil and its methyl ester (HOME) with and without carburettor. Renew Energy 34(4):1009-1015. https://doi. org/10.1016/j.renene.2008.08.005

19. Yaliwal VS, Nataraja KM, Banapurmath NR, Gireesh NM, Tewari PG (2013) Honge oil methyl ester and producer gas-fuelled dual-fuel engine operated with varying compression ratios. Int J Sustain Eng 7(4):330-340. https://doi.org/10.1080/19397038.2013.837108

20. Roy MM, Eiji T, Nobuyuki K, Yuji H, Atsushi S (2009) Effect of fuel injection parameters on engine performance and emissions of a supercharged producer gas-diesel dual fuel engine. Society of Automotive Engineers. Paper No. 2009-01-1848. https://doi. org/10.4271/2009-01-1848

21. Dhole AE, Yarasu RB, Lata DB (2016) Investigations on the combustion duration and ignition delay period of a dual fuel diesel engine with hydrogen and producer gas as secondary fuels. Appl Therm Eng 107:524-532. https://doi.org/10.1016/jappltherm aleng.2016.06.151

22. Halewadimath SS, Yaliwal VS, Banapurmath NR, Sajjan AM (2020) Influence of hydrogen enriched producer gas (HPG) on the combustion characteristics of a CRDI diesel engine operated on dual-fuel mode using renewable and sustainable fuels. Fuel 270:117575. https://doi.org/10.1016/j.fuel.2020.117575

23. Bilal S, Bahattin T (2020) Experimental analysis of combustion performance of biodiesel absorbed pellets in a domestic boiler. Energy 201:117653. https://doi.org/10.1016/j.energy.2020.117653

24. Saravanan N, Nagarajan G (2020) Performance and emission studies on port injection of hydrogen with varied flow rates with Diesel as an ignition source. Appl Energy 87(7):2218-2229. https://doi. org/10.1016/j.apenergy.2010.01.014

25. Zhou JH, Cheung CS, Leung CW (2014) Combustion, performance and emissions of a diesel engine with $\mathrm{H} 2, \mathrm{CH} 4$ and $\mathrm{H} 2-\mathrm{CH} 4$ addition. Int J Hydrog Energy 39:4611-4621. https://doi.org/10.1016/j. ijhydene.2013.12.194 
26. Yasin K, Tarkan S, Levent Y, Ahmet SD, Somchai W (2016) Effect of hydrogen-diesel dual-fuel usage on performance, emissions and diesel combustion in diesel engines. Adv Mech Eng 1:1. https:// doi.org/10.1177/1687814016664458
Publisher's Note Springer Nature remains neutral with regard to jurisdictional claims in published maps and institutional affiliations. 